\title{
Structural style of intra-plate deformation, Central Indian Ocean Basin: evidence for the role of fracture zones
}

\author{
Jonathan M. Bull ${ }^{1}$ \\ Department of Geology and Geophysics, Edinburgh University, West Mains Road, Edinburgh EH9 3JW (United Kingdom)
}

(Received November 9, 1989; revised version accepted April 26, 1990)

\begin{abstract}
Bull, J.M., 1990. Structural style of intra-plate deformation, Central Indian Ocean Basin: evidence for the role of fracture zones. Tectonophysics, 184: 213-228.

The structural style of the intraplate deformation developed in the Central Indian Ocean Basin was investigated in an area $\left(78^{\circ} \mathrm{E}-82^{\circ} \mathrm{E}, 0^{\circ} \mathrm{S}-6^{\circ} \mathrm{S}\right)$ to the west of the Afanasy Nikitin seamount using an integrated data set of seismic reflection profiles from Edinburgh University and Lamont-Doherty Geological Observatory. The study area contains two fracture zones, which strike $\sim 005^{\circ} \mathrm{E}$ to $010^{\circ} \mathrm{E}$, with oceanic lithosphere (age range $-65-78 \mathrm{Ma}$ B.P.) younging westwards across them. No evidence for recent fault activity in the oceanic basement along the fracture zones could be detected in this area, although the close association between intraplate earthquakes and fracture zones elsewhere suggests reactivation of the fracture zones at upper mantle depths in a left lateral strike-slip sense. A statistical study was carried out into the first and second orders of deformation, long wavelength basement undulations and high-angle reverse faults respectively, and the relationships between them. The orientations of the axes of the undulations vary from $065^{\circ} \mathrm{E}$ to $085^{\circ} \mathrm{E}$ while the high-angle faults strike consistently at $090^{\circ} \mathrm{E}$ to $100^{\circ} \mathrm{E}$. The results of this analysis suggest that the high-angle faults are the result of the reactivation of two sets of pre-existing spreading-centre normal faults, one set originally facing towards the spreading centre and the other facing away. Furthermore, although the long wavelength undulations are not fault generated, the high-angle faults have modified the basement topography causing the accentuation of some of the basement highs. The observation that the undulations are not fault-generated is consistent with them being of flexural origin (including buckling of the crust and/or lithosphere).

Basement undulations are clearly discontinuous across fracture zones and the facing direction of faulting is also offset. This discontinuity, the orientation of the axes of the undulations, the presence of other strong oblique basement trends, and information from regional earthquake studies suggest that the deformation resulted from not only $\sim \mathrm{N}-\mathrm{S}$ compression as a result of the continental collision between India and Asia, but also left lateral strike-slip along fracture zones caused by the difference in resistance to plate motion between the continental collision to the north and subduction at the Sunda Arc to the northeast.
\end{abstract}

\section{Introduction}

Recent studies have documented the broad scale nature of the intra-plate deformation developed in the Central Indian Ocean Basin (Fig 1.) (Weissel et al., 1980; Geller et al., 1983; Neprochnov et al., 1988; Stein and Weissel, 1990), making it clear that the Indo-Australian plate is not behaving

\footnotetext{
Present address: Department of Geology, University of Southampton, Highfield, Southampton SO9 $5 \mathrm{NH}$ (United Kingdom).
}

rigidly as required by the conventional plate tectonic theory. The observation of this deformation, together with evidence for non-closure of the plates around the Indian Ocean Triple Junction which is likely to have been caused by deformation within the Indian plate (Minster and Jordan, 1978), led to the development of the idea of a diffuse plate boundary in the Central Indian Ocean (Weins et al., 1986). Using a plate geometry with an Indo-Arabian plate separated from an Australian plate by this diffuse plate boundary, Demets et al. (1988) achieved closure around the Indian Ocean Triple Junction for the period $5 \mathrm{Ma}$ to the present. 
The intra-plate deformation, which in the Central Indian Ocean Basin extends from $-5^{\circ} \mathrm{N}$ to $10^{\circ} \mathrm{S}$ and from $\sim 78^{\circ} \mathrm{E}$ to the Ninetyeast Ridge, manifests itself in three principal forms. Firstly, a diffuse zone of large magnitude earthquakes (Sykes, 1970; Stein and Okal, 1978; Bergman and Solomon, 1985), whose principal axes of maximum compression strike $\mathrm{N}-\mathrm{S}$ close to the Indian subcontinent but become $\mathrm{E}-\mathrm{W}$ towards the centre of the Indo-Australian plate at the southern end of the Ninetyeast Ridge. Secondly, localised high heat flow, up to $50 \mathrm{~mW} / \mathrm{m}^{2}$ above the regional level of about $60 \mathrm{~mW} / \mathrm{m}^{2}$ typical for the oceanic crust of Late Cretaceous to early Tertiary age in this area, has also been documented (Geller et al., 1983; Stein and Weissel, 1990). This is thought to be associated with hydrothermal circulation along fault planes (Cochran et al., 1987). The third manifestation is the tectonic deformation visible on seismic profiles (Eittreim and Ewing, 1972; Weissel et al., 1980; Geller et al., 1983; Stein, 1984; Neprochov et al., 1988).

The tectonic deformation occurs on two spatial scales. A first order of deformation is represented by long wavelength $(100-300 \mathrm{~km})$, roughly $\mathrm{E}-\mathrm{W}$

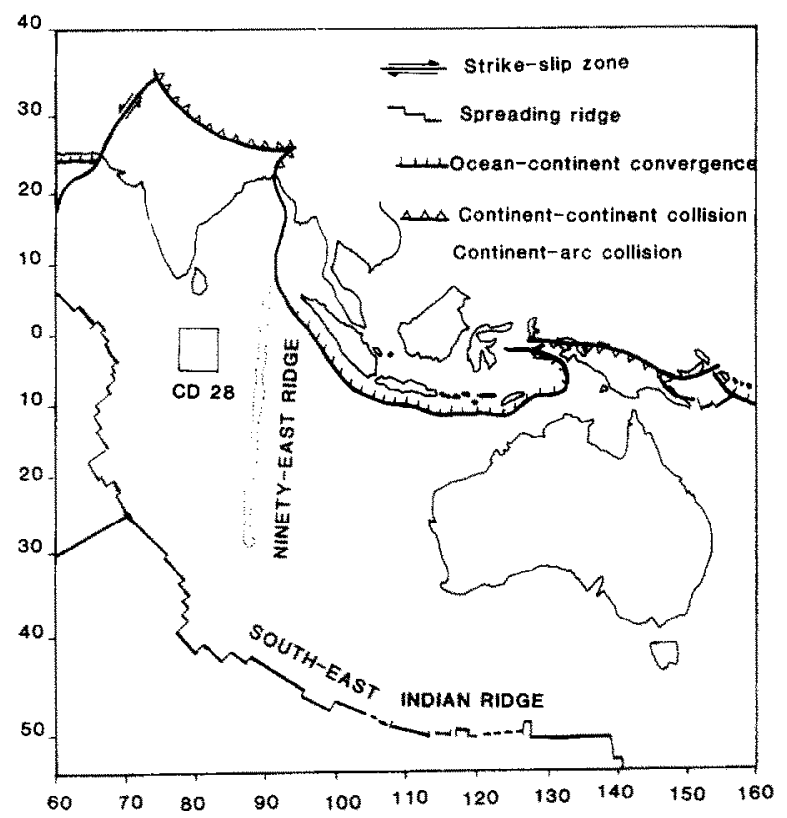

Fig. 1. The position of the Charles Darwin 28 cruise relative to the Indo-Australian plate (after Weissel et al., 1980). trending undulations of the oceanic basement and overlying oceanic and early Bengal Fan sediments with an amplitude of $1-2 \mathrm{~km}$. It is unclear as to whether the Moho is folded in parallel, although Seasat altimeter-derived gravity anomalies have been interpreted as suggesting a uniform crustal thickness (Haxby and Weissel, 1986). Superimposed on this first order of deformation is the second order represented by faulted blocks $5-20$ $\mathrm{km}$ in width, bounded by high-angle reverse faults which offset oceanic basement by up to $600 \mathrm{~m}$. The seismic profile shown in Fig. 2 illustrates the two orders of the deformation.

Weissel et al. (1980) suggested that the intraplate deformation might be associated with the phase of Himalayan uplift that resulted from the collision of India with Asia during the Late Miocene. The onset of deformation in the Central Indian Ocean, which is marked by a regional unconformity separating pre- and syn-deformational sediments, occurs at 7 Ma. However, O.D.P. Leg 116 evidence (Cochran et al., 1987) suggests that the Himalayan uplift had already begun by the Early Miocene (17Ma). Continuing studies of the timing and magnitude of events in the Himalayas shed light on this discrepancy. For example, a recent study of the Tibetan plateau suggests that much of the uplift and extension there have occurred as recently as the past -5 m.y. (Dewey et al., 1988; Shackleton and Chengfa, 1988). The uplift of the Tibetan plateau has been modelled by England and Houseman (1988) as a consequence of delamination of a thickened lithospheric root. If lithosphere shortening and thickening ceased when delamination and uplift started, then continued convergence between India with Asia, has forced shortening to be accommodated in other areas. A renewal of deformation in the Himalayas (Zeitler, 1985) may mark this accommodation as well as the onset of deformation in areas as widely separated as the Tien Shan (Windley et al., 1990) and the Central Indian Ocean.

In October 1987 scientists aboard the "Charles Darwin" (CD 28) surveyed an area just to the west of the Afanasy Nikitin Seamount in the Central Indian Ocean Basin (Fig 1.) In order to investigate the relationships between the high-angle faulting, the basement undulations and several fracture 

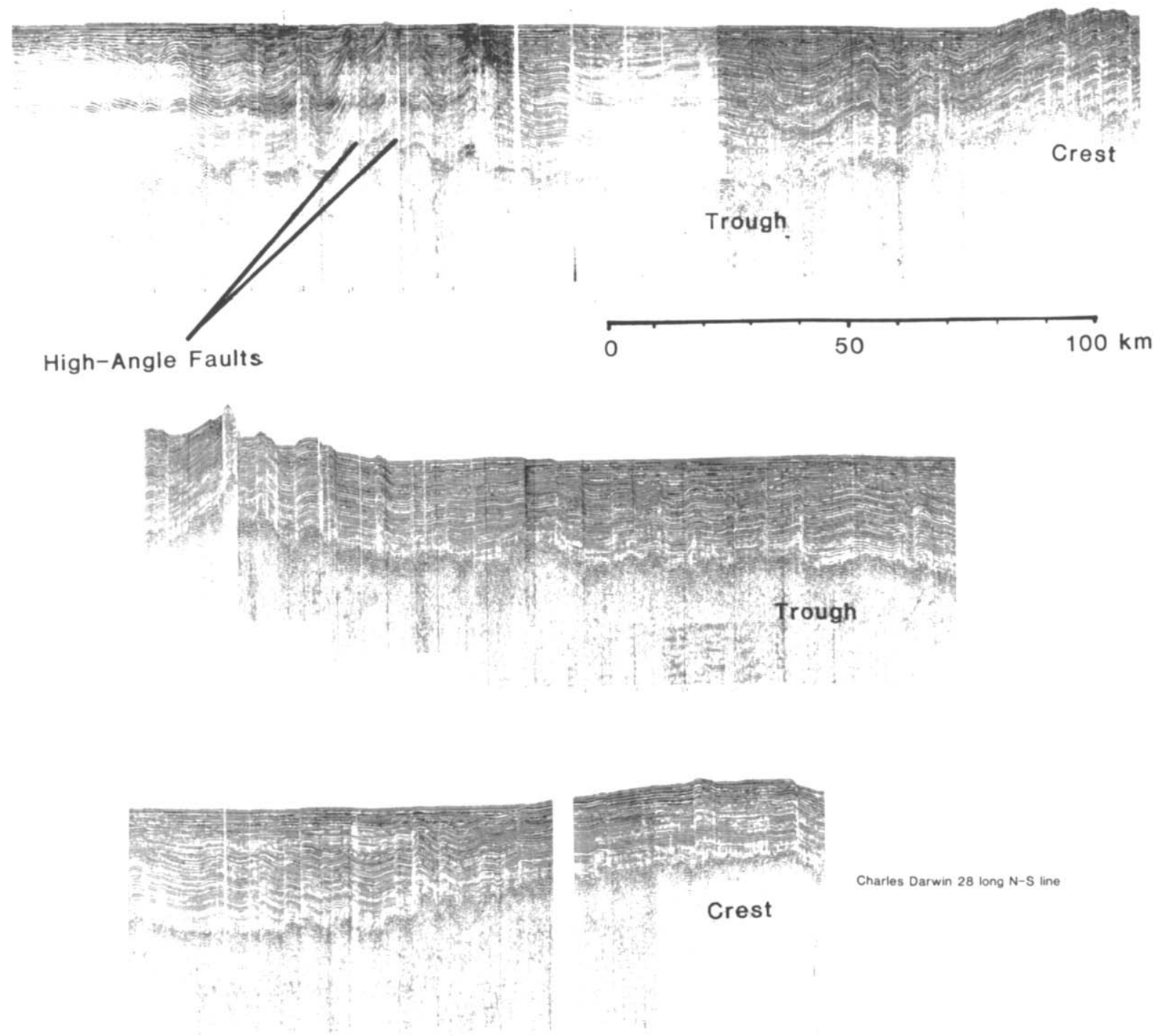

Charles Darwin 28 long $\mathrm{N}-\mathrm{S}$ line

Crest

Fig. 2. Seismic profile (position shown in Fig. 3) showing the two orders of the deformation; the long wavelength undulations and the high-angle faults.

zones developed in this area. The single and multichannel seismic lines were designed to integrate with pre-existing profiles to provide a data coverage as shown in Fig. 3. The purpose of this paper is to look in more detail at the structural style of the deformation.

\section{Fracture zones-undulation relationship}

Offsets in magnetic anomalies may be used to determine the approximate positions of fracture zones (Fig. 4). Within the study area are two fracture zones, both striking $\sim 005^{\circ} \mathrm{E}$ to $010^{\circ} \mathrm{E}$, a previously documented one called the Indrani (Sclater and Fisher, 1974) at $79^{\circ} \mathrm{E}$, and another one at $80.5^{\circ} \mathrm{E}$. Characteristic magnetic anomaly studies (Sclater and Fisher, 1974; LaBrecque et al., 1977; Shipboard Scientific Party, 1989) facilitated the determination of oceanic lithosphere age within each block between fracture zones: from $\sim 65 \mathrm{Ma}$ (anomaly 30) in the south, west of the Indrani, to $-78 \mathrm{Ma}$ (anomaly 33R) in the northeast around the O.D.P. Leg 116 sites.

On the seismic profiles, the fracture zones ap- 


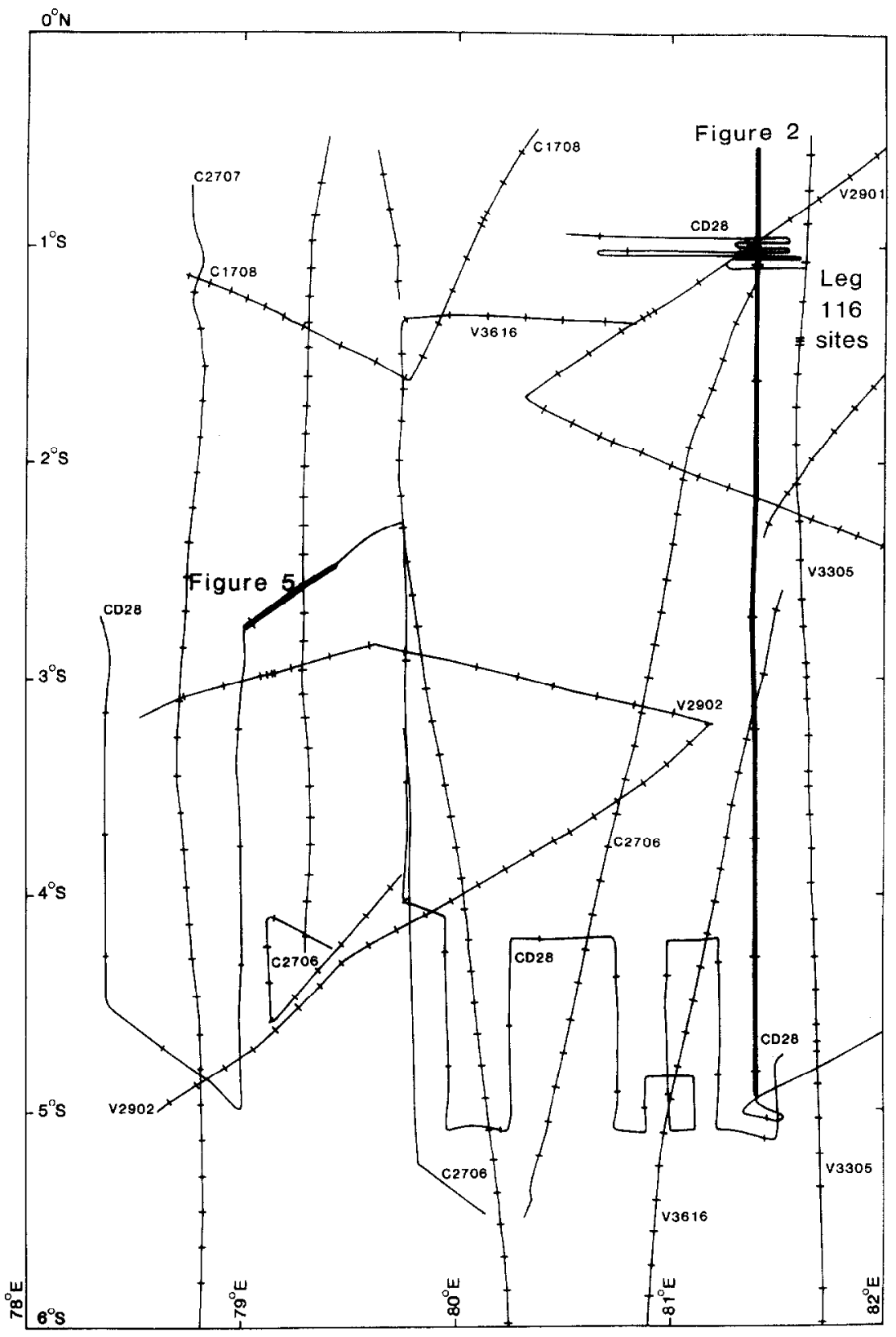

Fig. 3. Map showing spatial coverage within the survey area achieved by integration of Edinburgh University and Lamont-Doherty Geological Observatory seismic profiles. The positions of the multichannel profiles shown in Figs. 2 and 5 are indicated in bold.

pear as a rise in oceanic basement, to the younger crust on their western sides, as plate-cooling models would predict (Parsons and Sclater, 1977). Sediments onlap towards the younger lithosphere. Because earthquake focal mechanism solutions from the intraplate deformation area suggest fracture zone reactivation in a strike-slip sense, some recent fault activity in the fracture zones was expected. However, no deformation could be detected in the sediments likely to have been caused by reactivation of the fracture zones at any time since their formation (Fig. 5). Neprochnov et al. (1988, fig. 5) show another crossing of the Indrani in which there is also no evidence for reactivation. However, a fracture zone on the west flank of the Afanasy Nikitin Seamount does show recent re- 
activation (Scrutton and Bull, in prep.) and we suggest that fracture zone reactivation during deformation has been selective, perhaps being concentrated on the weakest mechanical fractures.

Although data quality on the older seismic profiles is highly variable, oceanic basement is nearly always clearly visible. This enabled the production of a contour map of basement topography, with reasonable spatial data coverage (Fig. 6), showing the position of the Indrani fracture zone as a clear, linear, $005^{\circ} \mathrm{E}-010^{\circ} \mathrm{E}$ striking feature. The fracture zone at $80.5^{\circ} \mathrm{E}$ is far less well defined and its position is, in places, indeterminate.

Within the survey area, the wavelength of the

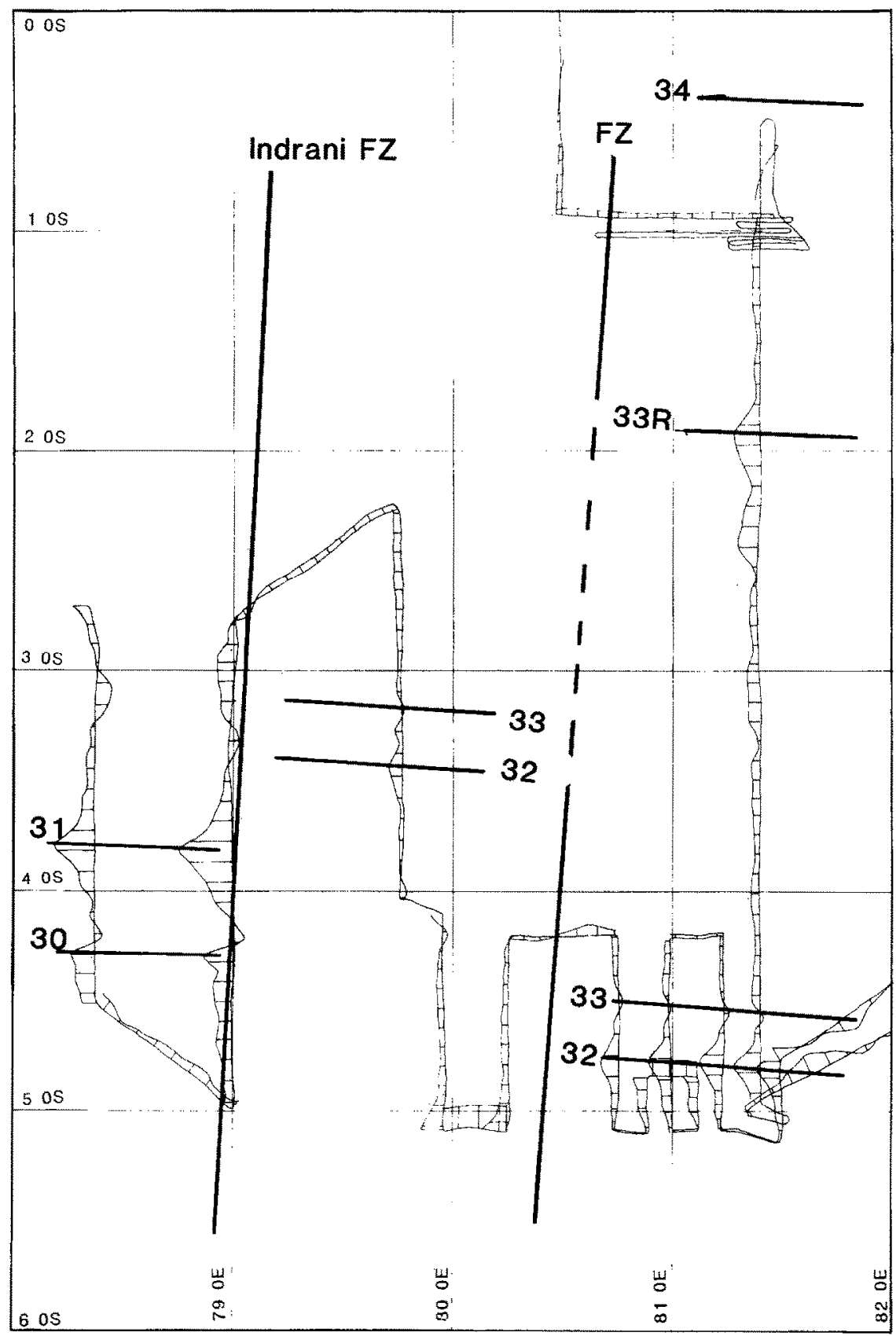

Fig. 4. Magnetic anomalies along profile and the positions of the fracture zones; the oceanic lithosphere youngs to the west across the fracture zones. Lithospheric age ranges from $\sim 65 \mathrm{Ma}$ (anomaly 30 ) in the southwest to $\sim 78 \mathrm{Ma}$ (anomaly 33R) in the northeast. 
undulations is $150-200 \mathrm{~km}$ with an amplitude of 1-2 km. The long-wavelength undulations, in general, strike $-070^{\circ} \mathrm{E}$, but are discontinuous across fracture zones, with the frequent juxtaposition of highs and lows. There is a suggestion that the axes of the undulations within each fracture zone block rotate slightly from roughly $085^{\circ} \mathrm{E}$ west of the Indrani to $065^{\circ} \mathrm{E}$ east of the $080.5^{\circ} \mathrm{E}$ fracture zone. Certainly, the strong NE or ENE and NW basement trends (Fig. 6) suggest a more complex stress regime than that given by simple, homogeneous, $\sim \mathrm{N}-\mathrm{S}$ compression previously thought to be the principal driving force in this area. The manner in which the fracture zones striking $005^{\circ} \mathrm{E}-010^{\circ} \mathrm{E}$ break up the continuity of the roughly $070^{\circ} \mathrm{E}$ undulations is reflected in the patchy character of Seasat free-air gravity anomaly contours (J.K. Weissel, pers. commun., 1986). In detail, these anomalies are rarely continuous for more than $\sim 150 \mathrm{~km}$ in the $\mathrm{E}-\mathrm{W}$ direction. roughly the spacing of the main fracture zones.

We have considered the possibility that some of the basement undulations are original features of the oceanic basement topography. From close examination of the seismic profiles for areas of sediment onlap onto basement and by the production of a total sediment thickness contour map (Fig. 7), it is possible to make some comments

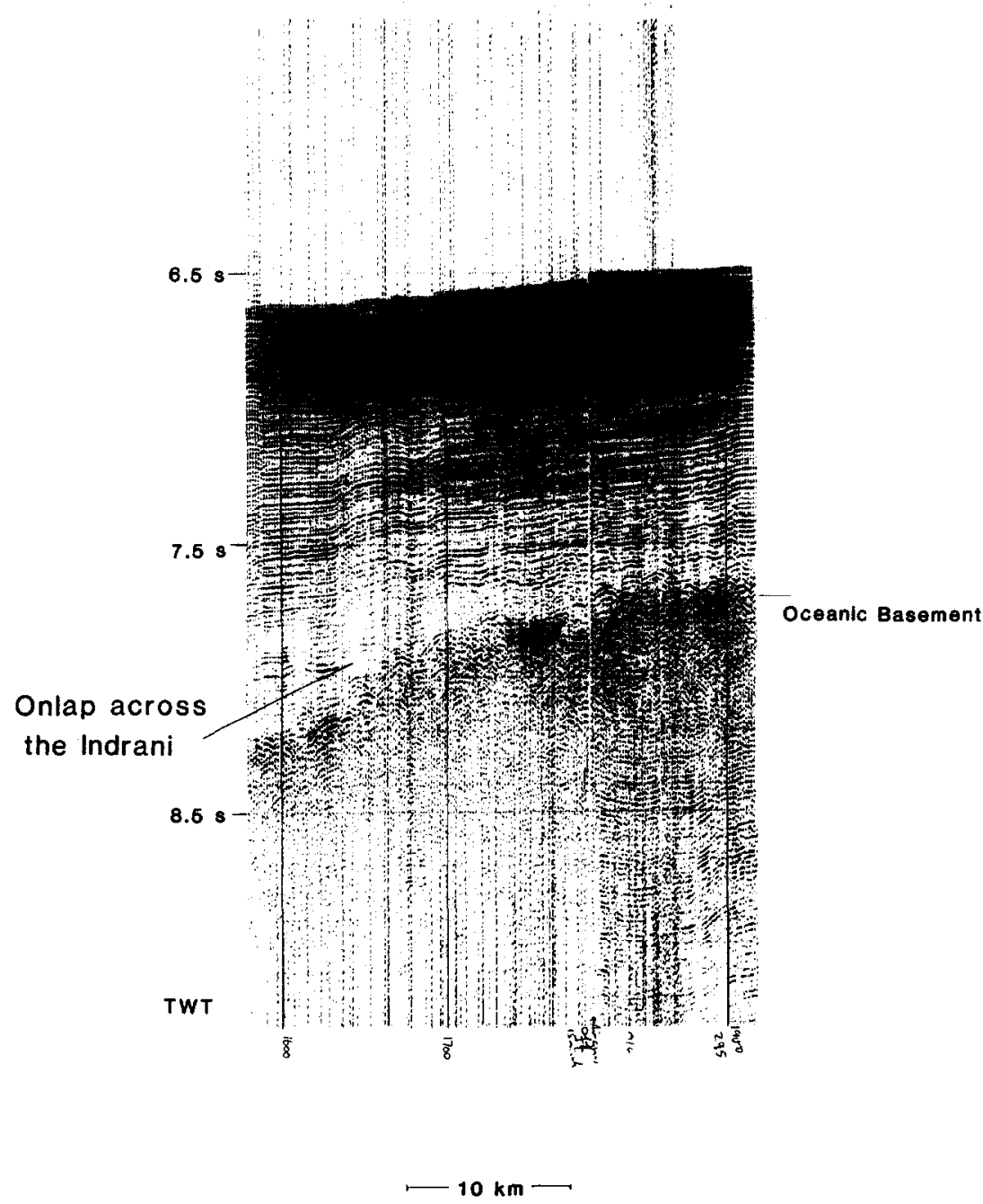

Fig. 5. The Indrani fracture zone profiled obliquely during the "Charles Darwin" 28 cruise. There is no evidence for reactivation of the fracture zone in the sediments or the basement. 
about the original topography. The region west of the Indrani at $4-5^{\circ} \mathrm{S}$ that includes two undulation crests and an intervening trough was originally an elevated area (as revealed by sediment onlap) which was later reinforced by the subsequent deformation to become a basement high. The area in the easternmost fracture zone block around $5^{\circ} \mathrm{S}$ was also an elevated area, although this was not

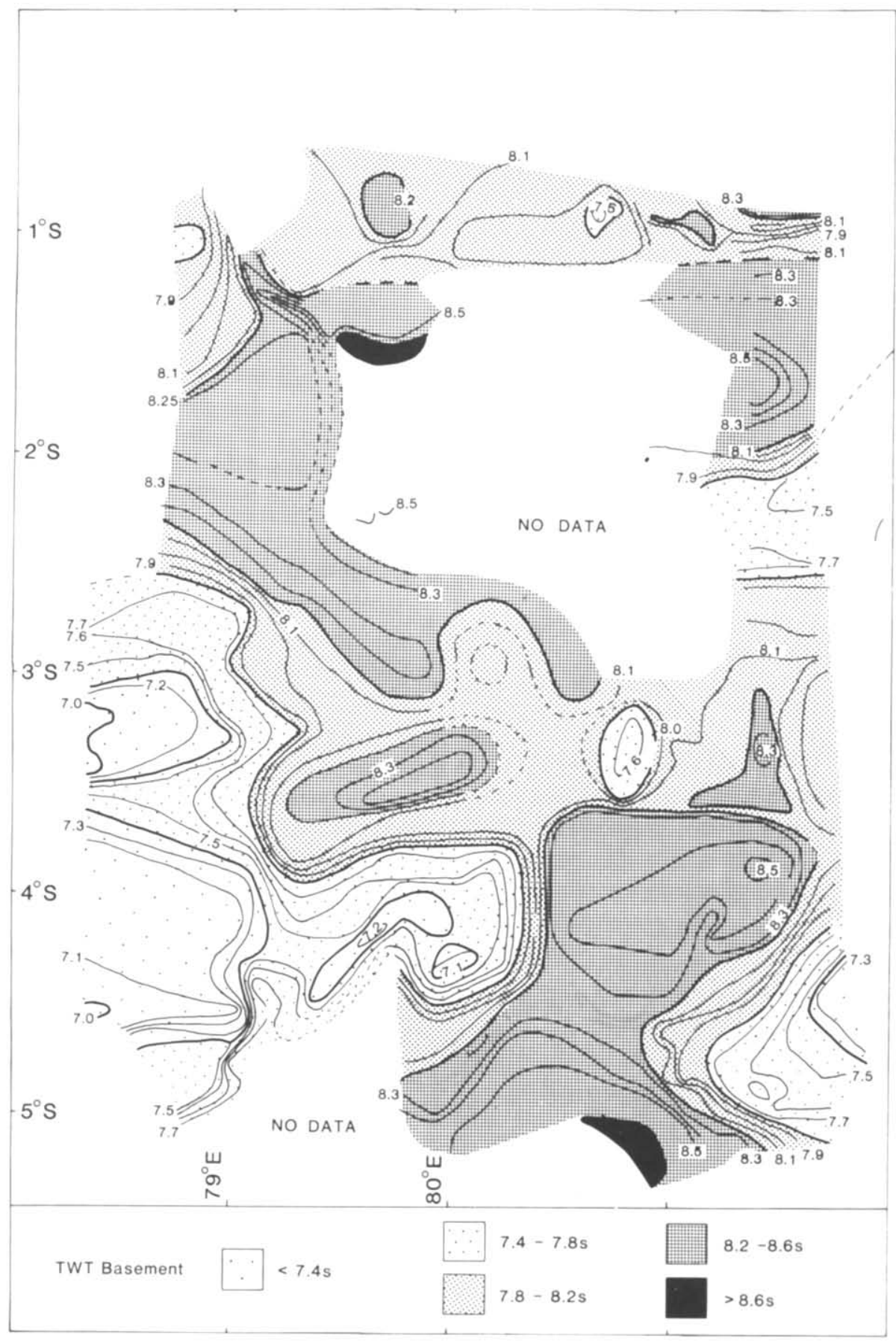

Fig. 6. Contour map of oceanic basement in TWT (seconds). The Indrani fracture zone can be observed as a clear, linear, $10^{\circ} \mathrm{E}$ striking feature at $79^{\circ} \mathrm{E}$ while the position of the other fracture zone is less clear. The $-70^{\circ} \mathrm{E}$ striking basement undulations are clearly offset across the fracture zones. 


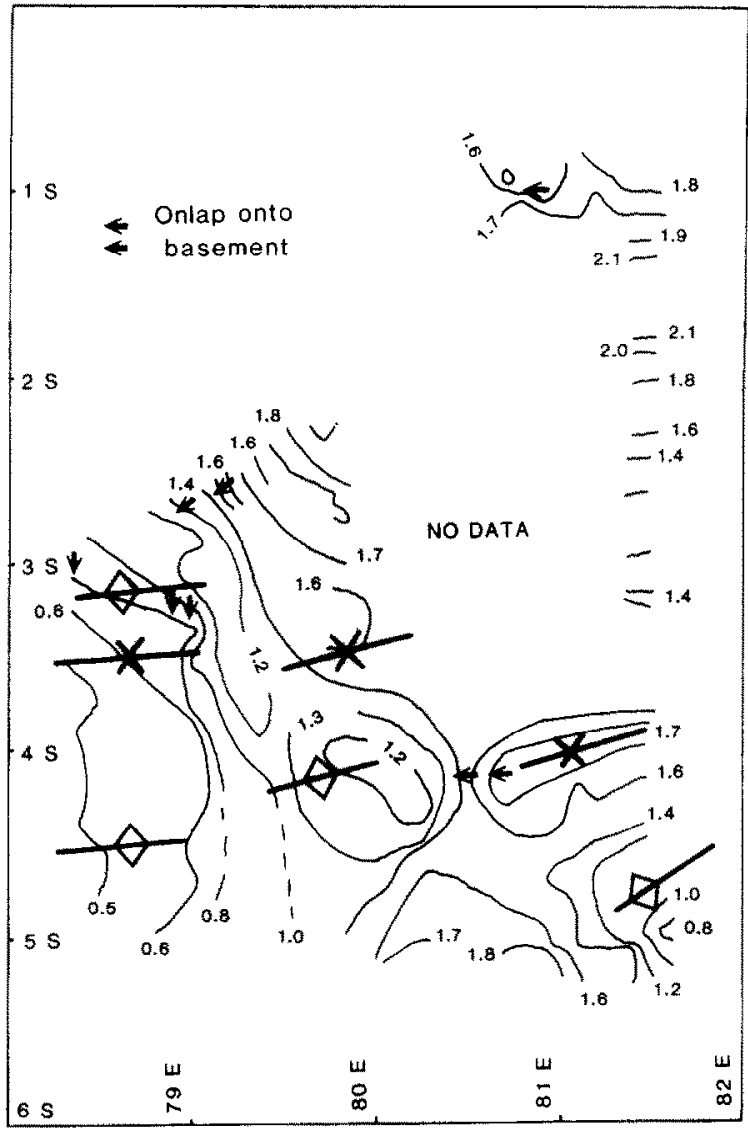

Fig. 7. Isopach map of total sediment thickness. The thickness of sediments reduces from north to south with increasing distance from their source. Arrows indicate the principal areas of sediment onlap onto oceanic basement indicating areas of upstanding basement prior to deformation. The axes of the underlying basement undulations are indicated.

reinforced. Elsewhere, for example around the O.D.P. Leg 116 sites at $1.0^{\circ} \mathrm{S} 80.2^{\circ} \mathrm{E}$ (Shipboard Scientific Party, 1989; Bull and Scrutton, in press), there is evidence for the abyssal hill topography similar to that widely found in the Pacific today, an area of similar sea-floor spreading rate. The two elevated areas mentioned are perhaps features too large to be abyssal hills, which typically have relief of 100-200 m (Luyendyk, 1970; Macdonald and Luyendyk, 1985), and are best described as low plateaus with basement elevations of $\sim 800$ $900 \mathrm{~m}$ above their surroundings. The origin of these plateaus may be closely related to that of the Afanasy Nikitin Seamount which lies close to the eastern edge of the survey area. In general, it appears that the original basement topography was either shorter wavelength (abyssal hills) or longer wavelength (plateaus) than the undulations and did not significantly affect the deformation style and pattern.

\section{Fault analysis and the fault-undulation relationship}

The second order of deformation represented by the high-angle reverse faults is highly variable in nature. The amplitude, throw direction (sense) and spacing of the faults appear, on preliminary inspection of the seismic profiles, to be complex. However, nearly all the faults have two common characteristics: oceanic basement is offset in a reverse sense; and the faulted sediments can be divided into a lower pre-deformational unit and an upper syn-deformational unit, with the onset of deformation dated as approximately $7 \mathrm{Ma}$ (Cochran et al., 1987). Figure 8 shows an annotated seismic section, shot north-south through the ODP Leg 116 sites, showing two typical faults.

Where the density of Edinburgh University lines was high, for example around the O.D.P. Leg 116 sites and around $81^{\circ} \mathrm{E}, 5^{\circ} \mathrm{S}$ (see Fig. 9), it was possible to follow a few of the high-angle faults along strike for as far as $\sim 40 \mathrm{~km}$. However, more generally, it was not possible to trace the majority of faults between lines only $10 \mathrm{~km}$ apart, suggesting a mean fault length of less than $10 \mathrm{~km}$. Where faults could be followed their strike was found to be roughly $090^{\circ} \mathrm{E}$ to $100^{\circ} \mathrm{E}$ (for example, see Fig. 9), in agreement with Weissel et al. (1980). This orientation, which is perpendicular to the the strike of the fracture zones, the manner in which they offset oceanic basement, and their short length resulting in an en echelon pattern, are all characteristic of the fault fabric found parallel to spreading-centres. Therefore, it seems likely that the faults are the result of the reactivation about 7 $\mathrm{Ma}$ of the pre-existing spreading-centre fabric.

The Edinburgh University profiles $(\sim 3520 \mathrm{~km}$ of data) were analysed using simple non parametric statistical techniques to see if any association could be detected between the high-angle faults and the first order of deformation, the long wavelength undulations. A histogram of fault spacing taken from the $\mathrm{N}-\mathrm{S}$ profiles is shown in Fig. 10A with a mean and median spacing of $6.6 \pm 0.3 \mathrm{~km}$ 
and $4.8 \mathrm{~km}$ respectively. This is comparable to the thickness of the oceanic crust. Fault spacing was measured from the offset of the sediment-basement interface. After allowing for end of profile effects caused by line changes (which probably add a few erroneous small spacings) the trimmed mean (which sorts the data and removes the top and bottom $5 \%$ ) of $5.9 \mathrm{~km}$ is probably a more realistic value. This sort of spacing is similar to the the fault generated topography of $4-8 \mathrm{~km}$ found on the East Pacific Rise today (Searle, 1984; Macdonald and Luyendyk, 1985) which has a spreading-rate comparable to the approximate $6 \mathrm{~cm} / \mathrm{yr}$ rate developed in the Central Indian Ocean at
65-78 $\mathrm{Ma}$ (anomalies 30-33R of Sclater and Fisher, 1974).

Within the survey area, we found that an approximately equal number of faults downthrow towards the spreading centre (to the south: inward) as downthrow away from it (outward), in contradiction of earlier studies which suggested that the vast majority of faults downthrow towards the spreading-centre. Here only a very small majority downthrow towards the spreading centre. The low dip angle of the basement reflector means that depth conversion would not change the facing direction of any of the faults. When the trimmed mean spacing between faults downthrowing in the

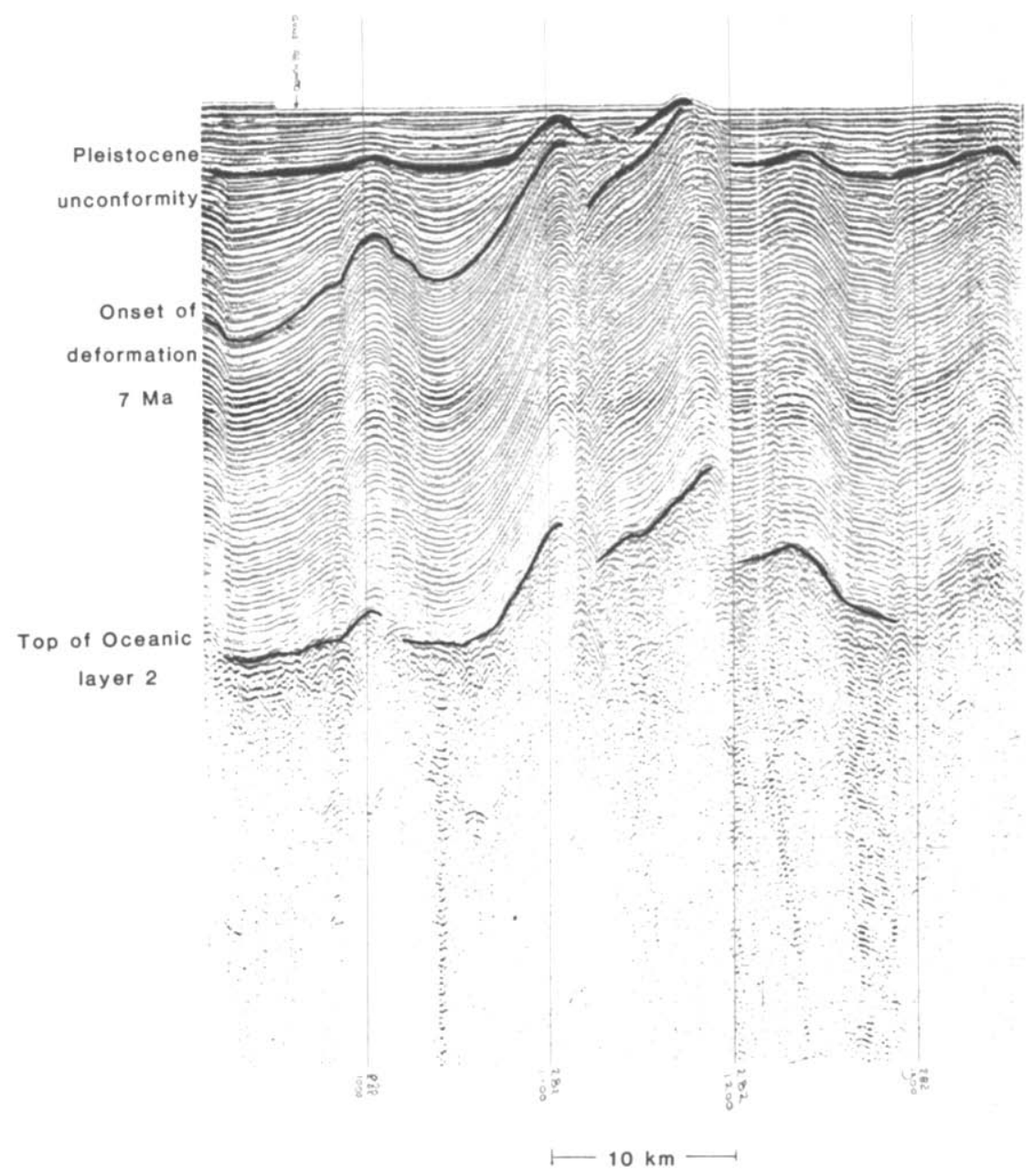

Fig. 8. Seismic profile illustrating two of the high-angle faults. The profile is part of Fig. 2 through the O.D.P. Leg 116 sites (see Fig. 3). The high-angle faults always offset basement and the sediments can be divided into a pre-deformational and syndeformational units, separated by an unconformity at $7 \mathrm{Ma}$ (Cochran et al., 1987). 
same direction are compared, we found that the spacing for the outward facing is $11.0 \mathrm{~km}$ while that for the inward facing is $8.0 \mathrm{~km}$ (see Fig. 10B, C). The corresponding median spacings for all the data are $7.8 \mathrm{~km}$ for the outward facing and $5.0 \mathrm{~km}$ for the inward facing faults. It is possible to test whether or not these median spacings arise from different populations by using the Mann-Whitney test. When this is done, it is found-with $95 \%$ certainty-that the fault spacing medians come from different populations. This suggests that prior to reactivation there were two fault sets with different spacing characteristics. On the East Pacific Rise, Searle (1984) distinguished two normal fault sets with different mean fault spacings, one set inward-facing with a mean spacing of $1.7 \pm 0.07$ $\mathrm{km}$ and another set, more widely spaced and outward facing, with a mean spacing of $2.55 \pm 0.24$ $\mathrm{km}$. These mean spacings are much smaller than those described above from the survey area. The larger mean fault spacing in the survey area may suggest that approximately one in four or five of the faults generated at the spreading-centre has been reactivated to an extent detectable on the seismic profiles by the subsequent deformation.

The magnitude of the fault throw varies from an offset of basement of $\sim 600 \mathrm{~m}$ to that so small as to be undetectable on the seismic sections. No relationship could be found between the magnitude of fault throw and position relative to the long wavelength undulations. Examples of the "Deformation Fronts" noted by Weissel et al. (1980) are found where there are zones of intense fault activity. However, these could not be correlated with the longer wavelength phenomena. A complementary question is to what degree has the second order of deformation contributed to the first order? That is, is the topography represented by the long-wavelength undulations fault generated? To answer this it is necessary to investigate the relationship between the sense of faulting direction of downthrow) and the direction of slope of the underlying oceanic basement. Faults occurring on the CD 28 lines were classified according to the sense of throw (south or north) and the direction upslope of the underlying oceanic basement (south or north). This gave four different classes (Table 1), which we tested for association via the chi-squared test. For the entire survey, there is an association between sense of faulting and slope of basement such that faults tend to downthrow downslope accentuating the crests of the undulations. However, if certain parts of the survey were tested for association, for example the

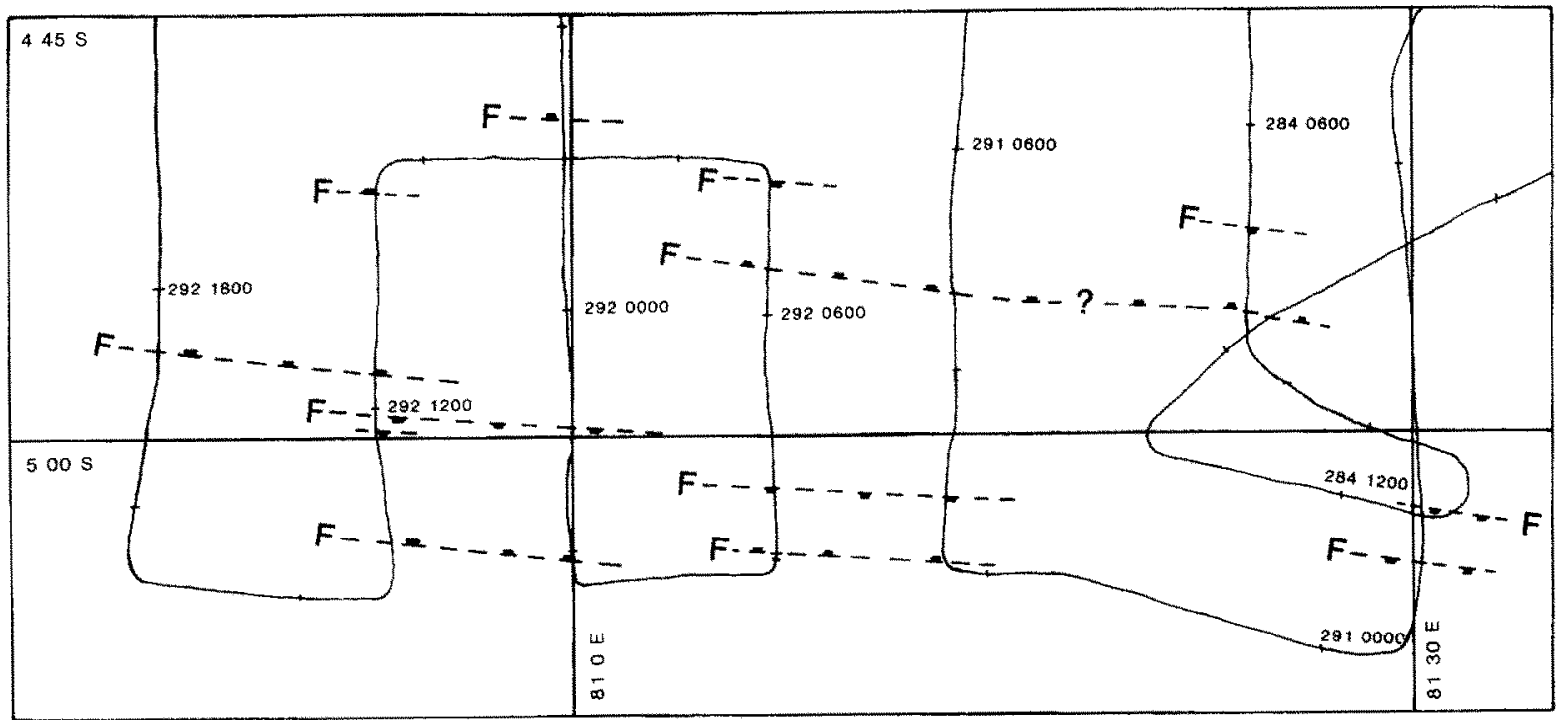

Fig. 9. Orientations of the principal faults in the southern grid area. Only the major faults and those that could be traced between lines are shown. 
long CD $28 \mathrm{~N}-\mathrm{S}$ line at $81.5^{\circ} \mathrm{E}$, no relationship is suggested. So, although there is a relationship between the first and second orders of deformation, it is not a simple one that can be applied equally to all areas.

Although, as mentioned previously, the planform of the sense of faulting (direction of down- throw) is complex, it is possible to map areas in which the majority of faults have the same sense. In Fig. 11 the sense of faulting is shown overlying the contour map of oceanic basement. Two important conclusions can be drawn from this.

Firstly, there is a change in the sense of throw across the well-formed crests, with faults down-
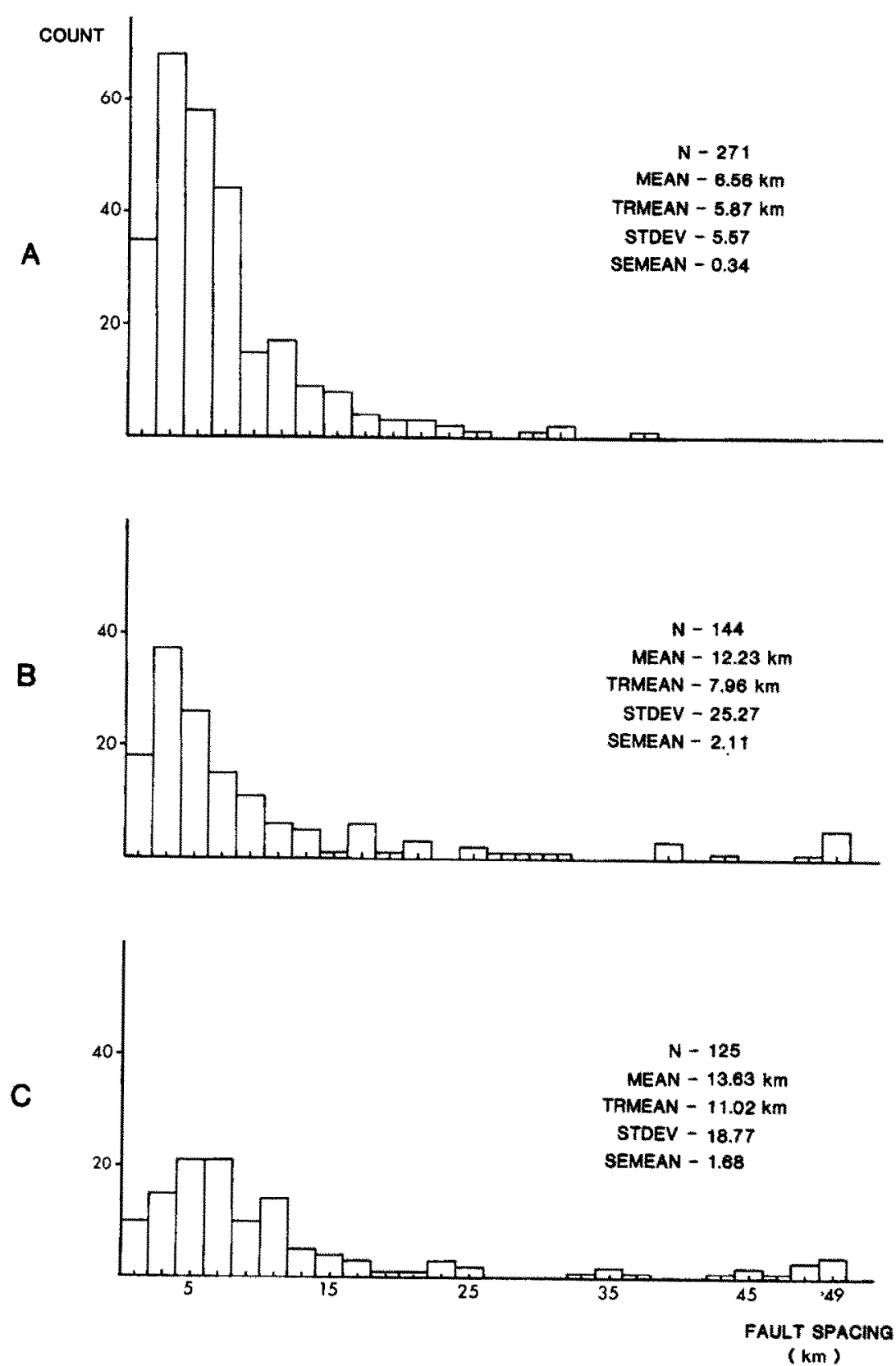

Fig. 10. Histograms of fault spacing for N-S profiles. (A) Between all the faults. (B) Between faults downthrowing to the south. (C) Between faults downthrowing to the north. 


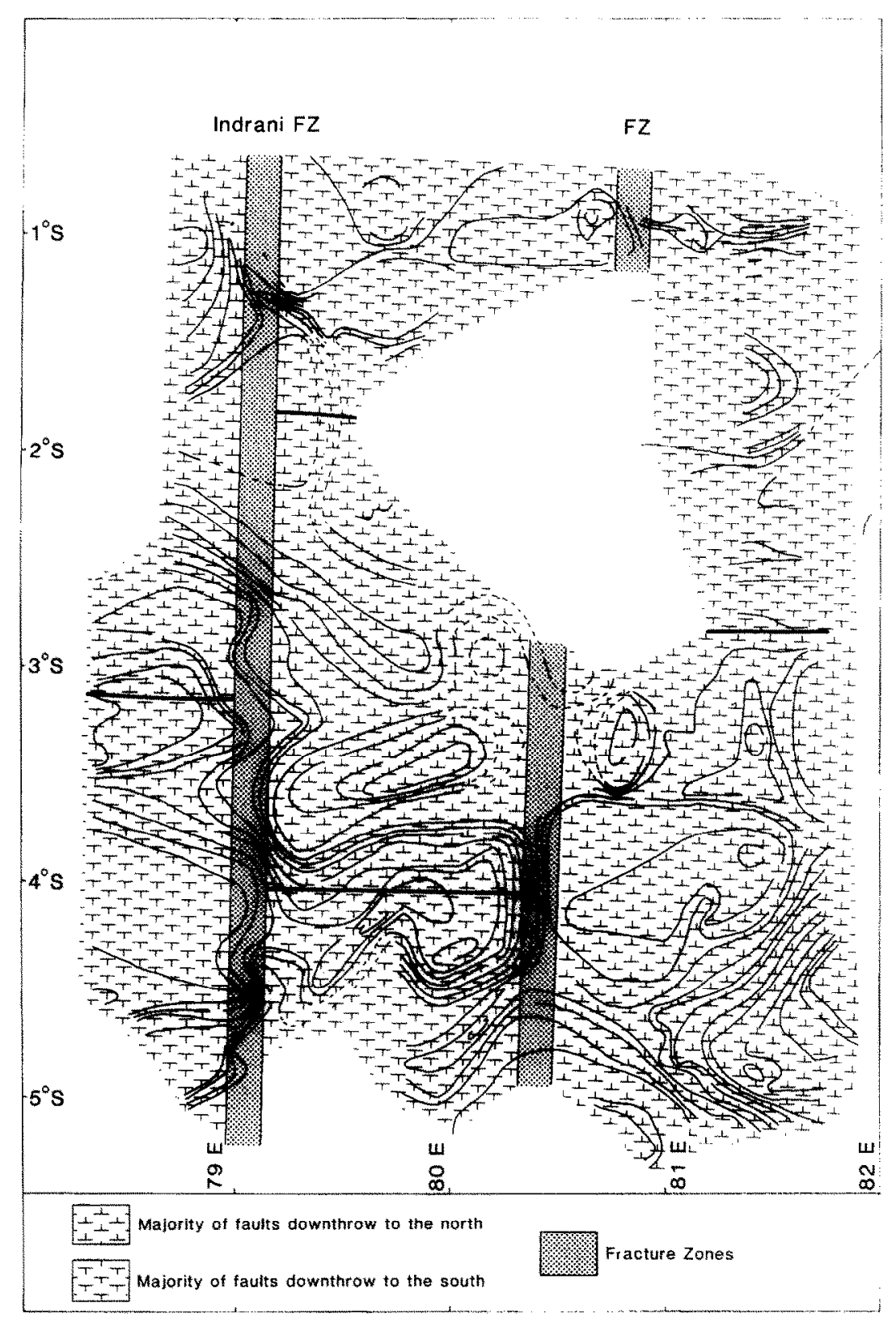

Fig. 11. The general relationship between fracture zones, basement topography and fault sense.

throwing downslope on either side, as suggested by the statistical analysis (e.g., west of the Indrani at $3^{\circ} \mathrm{S}$ and in the centre block between fracture zones at $4^{\circ} \mathrm{S}$ ). More commonly, however, there is no relationship between the sense of faulting and the underlying basement topography at less wellformed crests and through the troughs (for example, in the centre fracture zone block at $3.5^{\circ} \mathrm{S}$ and for the long $\mathrm{CD} \mathrm{N}-\mathrm{S}$ line). It would seem that although the first order of deformation is not formed by the second order, it is modified by it as manifested by the accentuation of some of the crests. This has produced the "sharp crest-broad trough" topography commonly seen on the seismic profiles from this area. The lack of a general relationship between the high-angle faulting and 
TABLE 1

Statistical study of the fault/undulation relationship *

\begin{tabular}{|c|c|c|c|c|c|c|c|}
\hline Profile No. & $N$ & $T 1$ & $T 2$ & $T 3$ & $T 4$ & $S 1$ & $S 2$ \\
\hline FA282 & 69 & 14 & 15 & 9 & 15 & 32 & 37 \\
\hline FA291A & 10 & 5 & 0 & 1 & 0 & 9 & 1 \\
\hline FA291B & 15 & 7 & 0 & 0 & 2 & 13 & 2 \\
\hline FA292A & 6 & 0 & 0 & 3 & 3 & 3 & 3 \\
\hline FA292B & 6 & 0 & 0 & 1 & 2 & 3 & 3 \\
\hline FA292C & 14 & 3 & 0 & 4 & 1 & 13 & 1 \\
\hline FA293A & 14 & 0 & 0 & 2 & 10 & 2 & 12 \\
\hline FA293B & 14 & 0 & 0 & 3 & 6 & 5 & 9 \\
\hline FA294 & 32 & 15 & 2 & 4 & 0 & 30 & 2 \\
\hline FA295 & 52 & 2 & 7 & 0 & 9 & 12 & 40 \\
\hline FA297 & 40 & 2 & 6 & 3 & 12 & 6 & 34 \\
\hline FA295SW & 5 & 4 & 1 & 0 & 0 & 4 & 1 \\
\hline FA296NW & 7 & 0 & 0 & 0 & 2 & 0 & 7 \\
\hline Total & 284 & 52 & 31 & 32 & 62 & 132 & 152 \\
\hline
\end{tabular}

* $\mathrm{N}$ is the total number of faults.

$T 1$ is the number of faults where basement rises to the south that downthrow to the north.

$T 2$ is the number of faults where basement rises to the south that downthrow to the south.

$T 3$ is the number of faults where basement rises to the north that downthrow to the north.

$T 4$ is the number of faults where basement rises to the north that downthrow to the south.

$S 1$ is the total number of faults which downthrow to the north.

$S 2$ is the total number of faults which downthrow to the south.

The number of faults which occur on flat basement is given by (N-T1-T2-T3-T4).

the long-wavelength undulations supports an origin that is fundamentally flexural (including buckling) for the undulations.

Second, the fracture zones clearly offset regions of the same fault sense and is perhaps the most convincing evidence to support the hypothesis that the faults are the result of the reactivation of the pre-existing spreading-centre formed fabric. Small variations in the environment of formation of the fault fabric at the spreading centre could have produced the offset in fault sense observed across the fracture zones.

\section{Discussion}

The large amount of intraplate seismicity recorded in the northern part of the Indo-Australian plate has been dominated by thrust faulting on - E-W striking faults and left lateral strike-slip motion on faults striking $\sim \mathrm{N}-\mathrm{S}$ (Stein and Okal, 1978; Bergman and Solomon, 1985). Stein and Okal (1978) suggested that the left-lateral strikeslip motion along the northern part of the Nine- tyeast Ridge marked the decoupling between the Indian and Australian halves of the plates as a consequence of changes in plate boundary on either side of the ridge. There is more resistance to northward plate motion west of the ridge where India collides with Asia, than to the east where oceanic crust subducts at the Sunda Trench. However, left-lateral strike-slip motion extends well to the west of the Ninetyeast ridge, as evidenced by focal mechanism solutions of several earthquakes showing nodal planes orientated parallel to the fracture zones. While no earthquakes have been recorded to date along fracture zones in the area discussed in this paper, the fracture zone immediately to the east of the survey area (the Indiri of Sclater and Fisher, 1974) is seismically active (Bergman and Solomon, 1985).

The compressive stresses deduced from earthquake focal mechanism studies (Stein and Okal, 1978; Bergman and Solomon, 1985) and derived from plate boundary forces (Cloetingh and Wortel, 1986) would give a far simpler tectonic fabric than that actually observed. The lack of continuity of 
the undulations across the fracture zones, the orientation of the axes of the undulations, the strong oblique NE or ENE and NW basement trends, and the earthquake source mechanisms suggest that the fracture zone fabric has substantially modified the stress regime. An apparent change in strike of the undulations towards the Afanasy Nikitin Seamount suggests that this feature may also have modified the stress system. The selective reactivation of the fracture zones may have provided little effective stress linkage across the fracture zones in some areas, with the formation of the long wavelength undulations taking place independently in each block.

In other areas, the apparent contradiction between the discontinuity of the undulations across fracture zones and the lack of surface expression of fracture zone reactivation needs to be addressed. Two possible explanations of this are that either the reactivation is not detectable within the resolution of the seismic profile data or, more likely, theology controls the tectonic behaviour.

High-magnitude shallow seismicity (both compressional and strike-slip) is absent in the intraplate deformation area (Bergman and Solomon, 1985; Zuber, 1987), probably because the low brittle strength of the oceanic crust and uppermost oceanic mantle allows very limited transmission of significant stresses away from their source (Bergman, 1986). Although, as discussed earlier, significant compressional deformation occurs at high crustal and possibly upper mantle levels, this has to be reconciled with the absence of evidence for high level strike-slip motion along the fracture zones. Sandwell and Schubert (1982) argue that fracture zones are not inherent zones of weakness since they support the bending stresses imposed by juxtaposed cooling lithosphere of different ages. They argue that below the fractured surface layer lies coherent oceanic lithosphere that is not significantly weaker than the surrounding lithosphere. However, in this area of the intraplate deformation, the strain rates and stress levels are much higher than those studied by Sandwell and Schubert (1982). The approximate N-S compression acts on $005^{\circ} \mathrm{E}-010^{\circ} \mathrm{E}$ striking fracture zones, and earthquake evidence is strong for a left lateral strike-slip regime controlled by fracture zones.
The lack of surface expression of reactivated fracture zones suggests a rheological control, such that at high crustal levels the fracture zones are not weaker than the surrounding lithosphere. However, in this area of unusually high compressive stress, the fracture zones have been reactivated at depth in a left lateral sense to allow the observed deformation to develop. This agrees with the experimental work of Richard and Krantz (1991), who suggest that not only does a previously faulted zone control the deformation of a strike-slip zone in sand-box experiments, but that reactivation of faults in a strike-slip sense can occur at depth without localised surface deformation. They attribute this difference in behaviour to the increasing importance of mechanical cohesion with decreasing depth. Alternatively this implied reduction in localised strike-slip offset with decreasing depth may simply be due to the reactivated slip not having penetrated to the surface yet. The relatively deep mantle seismicity $(25-40 \mathrm{~km})$ described by Bergman (1986) suggests a localised high strain rate, possibly due to buckling and consequently a deeper brittle-ductile transition than normal. The dynamic faulting has yet to reach the surface from such a deep nucleation point.

The manner in which the first and second orders of the deformation at shallow levels link into the deep structure, as described by thrust faulting earthquakes $25-40 \mathrm{~km}$ beneath the Bengal Fan, is still nuclear. There is no evidence to suggest, and it would seem unlikely on consideration of the conventional rheology for the oceanic lithosphere (e.g., Meissner and Wever, 1988), that the high-angle faults become less steeply dipping and join together in some form of décollement which is occasionally thrust faulted. Whole lithosphere buckling of an elastic-plastic lithosphere (McAdoo and Sandwell, 1985) is possible within the stress regime in the Indo-Australian plate as modelled by Cloetingh and Wortel (1986). (Buckling of a purely elastic lithosphere, as discussed by Weissel et al. (1980), requires stresses of unrealistically large magnitude). It is difficult to reconcile the observed seismicity-depth distribution with a simple lithospheric buckling model. The suggestion by King and Stein (1984) that the shallow first order 
of deformation (undulations) may be the consequence of thrust faulting at depth that has not penetrated to upper levels of the lithosphere seems to best reconcile the observed phenomenen and is consistent with the model proposed above for fracture zones. The high-angle faulting has been interpreted to result from the reactivation of the pre-existing spreading-centre formed fabric in response to the development of the undulations. The manner in which the shallow and deep structures interact requires further modelling using both finite element and sandbox techniques. However, it should be noted that at present there are no sufficiently deep reflection or refraction seismic data available to constrain these hypotheses.

\section{Conclusions}

From this study of the structural style of intraplate deformation the following principal conclusions can be made:

(1) The spacing, orientation (perpendicular to the fracture zones), length along strike, manner in which they offset basement, and the change in fault sense across fracture zones is consistent with the high-angle reverse faults resulting from the reactivation of the pre-existing spreading-centre formed fabric. Furthermore, there is evidence that the complex fault pattern is the result of the reactivation of both sets (inward and outward facing) of pre-existing normal faults.

(2) Symmetrical faulting on either side of some of the crests has led to accentuation of these highs. The lack of any general relationship between the first and second orders of deformation supports a flexural origin (including buckling) for the undulations.

(3) In the survey area the first and second orders of deformation are discontinuous across fracture zones. The orientation of the axes of the undulations and other basement trends, and regional seismicity studies suggest that the survey area has experienced not only compression but also left lateral strike-slip deformation. The latter developed from the interaction of plate boundary forces with the fracture zone fabric developed in this area.

\section{Acknowledgements}

I would like to thank the master, officers and crew of the "Charles Darwin" and the engineers of RVS "Barry" without whose expertise at sea this paper would not have been possible. I also thank Drs. R. Scrutton, R. Cheeney, I. Main and $M$. Johnson for their advice and suggestions. This work was supported by NERC grant GR3/6480.

\section{References}

Bergman, E.A., 1986. Intraplate earthquakes and the state of stress in the oceanic lithosphere. Tectonophysics, 132: 1-35.

Bergman, E.A. and Solomon, S.L., 1985. Earthquake source mechanisms from body wave inversion and intraplate tectonics in the Northern Indian Ocean. Phys. Earth Planet. Inter., 40: 1-23.

Bull, J.M. and Scrutton, R.A., in press. Sediment velocities and deep structure from wide-angle reflection data around ODP Leg 116 sites. In: J.R. Cochran, D.A. Stow, V., et al., (Editors), Proceedings of the Ocean Drilling Program, ODP Sci. Rep., 116. College Station, Tex.

Cloetingh, S. and Wortel, R., 1986. Stress in the Indo-Australian plate. Tectonophysics, 132: 49-67.

Cochran, J.R. and Leg 116 shipboard scientific party, 1987. Ocean Drilling Program, Collisions in the Indian Ocean. Nature, 330: 519-521.

Demets, C., Jordan, R.G. and Argus, D., 1988. Intraplate deformation and closure of the Australia-AntarcticaAfrica plate circuit. J. Geophys. Res., 93: 11877-11897.

Dewey, J.F., Shackleton, R.M., Chengfa, C. and Yiyin, S., 1988. The tectonic evolution of the Tibetan Plateau. Philos. Trans. R. Soc. London, Ser. A, 327: 379-413.

Eittreim, S.L. and Ewing, J., 1982. Midplate tectonics in the Indian Ocean. J. Geophys. Res., 77: 6413-6421.

England, P.C. and Houseman, G.A., 1988. The mechanics of the Tibetan Plateau. Philos. Trans. R. Soc. London, Ser. A, 326: $301-320$.

Geller, G.A., Weissel, J.K. and Anderson, R.N., 1983. Heat transfer and intraplate deformation in the central Indian Ocean. J. Geophys. Res., 88: 1018-1032.

Haxby, W.F. and Weissel, J.K., 1986. Evidence for small scale convection from Seasat altimeter data. J. Geophys. Res., 91: 3507-3520.

King, G.C.P. and Stein, R.S., 1984. Earthquake potential of active folds. Eos, Trans. Am. Geophys. Union, 65: 1113.

LaBrecque, J.L., Kent, D.V. and Cande, S.L., 1977. Revised magnetic polarity time scale for Late Cretaceous and Cenozoic time. Geology, 5; 330-335.

Luyendyk, B.P., 1970. Origin and history of abyssal hills in the northeast Pacific. Geol. Soc. Am. Bull., 81: 2237-2260.

Macdonald, K.C. and Luyendyk, B.P., 1985. Investigation of faulting and abyssal hill formation on the flanks of the East Pacific Rise $\left(21^{\circ} \mathrm{N}\right)$. Mar. Geophys. Res., 7: 515-535. 
McAdoo, D.C. and Sandwell, D.T., 1985. Folding of the oceanic lithosphere. J. Geophys. Res., 90: 8563-8569.

Meisner, R. and Wever, T., 1988. Lithospheric rheology: continental versus oceanic unit. In: M.A. Menzies and K.G. Cox (Editors), Oceanic and Continental Lithosphere. $J$. Petrol., Spec. Vol,: 53-61.

Minster, J.B., and Jordan, T.H., 1978. Present day plate motions. J. Geophys. Res., 83: 5331-5334.

Neprochnov, Y.P., Levchenko, O.V., Merklin, L.R. and Sedov, V.V., 1988. The structure and tectonics of the intraplate deformation area in the Indian Ocean. Tectonophysics, 156: 89-106.

Parsons, B. and Sclater, J.G., 1977. An analysis of the variation of ocean floor bathymetry and heat flow with age. $J$. Geophys. Res, 82: 803-827.

Richard, P. and Krantz, R.W., 1991. Experiments on fault reactivation in a strike-slip mode. In: P.R. Cobbold (Editor), Experimental and Numerical Modelling of Continental Deformation. Tectonophysics, in press.

Sandwell, D.T. and Schubert, G., 1982. Lithospheric flexure at fracture zones. J. Geophys. Res., 87: 4657-4667.

Sclater, J.G. and Fisher, R.L., 1974. Evolution of the East Central Indian Ocean with emphasis on the tectonic setting of the Ninetyeast Ridge. Geol. Soc. Am. Bull, 85: 683-702.

Searle, R., 1984. Gloria survey of the East Pacific Rise near 3.5 $\mathrm{S}$ : tectonic and volcanic characteristics of a fast spreading mid-ocean rise. Tectonophysics, 101: 319-344.

Shackleton, R.M. and Chengfa, C., 1988. Cenozoic uplift and deformation of the Tibetan Plateau: the geomorphological evidence. Philos. Trans. R. Soc. London, Ser. A, 327: $365-377$.
Shipboard Scientific Party, 1989. ODP Leg 116 Site Survey. In J.R. Cochran, D.A.V. Stow, et al. (Editors), Proceedings of the Ocean Drilling Program, Init. Rep., 116. College Station, Tex.

Stein, C.A., 1984. Part I: Heat Transfer, Seismicity and Intraplate Deformation in the Central Indian Ocean. Unpublished PhD Thesis, Columbia University, New York, N.Y. $151 \mathrm{pp}$.

Stein, C.A. and Weissel, J.K., 1990. Constraints on Central Indian Ocean thermal structure from heat flow, seismicity and bathymetry. Tectonophysics, 176: 315-332.

Stein, C. and Okal, E.A., 1978. Seismicity and tectonics of the Ninetyeast Ridge area: Evidence for internal deformation of the Indian plate, J. Geophys. Res.. 83: 2233-2246.

Sykes, L.R., 1970. Seismicity of the Indian Ocean and a possible nascent island arc between Ceylon and Australia. J. Geophys. Res., 75: 5041-5055.

Weins, D.A., Stein, S., Demets, C., Gordon, R.G. and Stein. C., 1986. Plate tectonic models for Indian Ocean "intraplate" deformation. Tectonophysics, 132: 37-48.

Weissel, J.K.. Anderson, R.N. and Geller, C.A., 1980. Deformation of the Indo-Australian plate. Nature, 287: 284-291

Windley, B.F., Allen, M.B., Zhang, C., Zhao, Z-Y.. Lang, G.R. 1990. Palaeozoic accretion and Cenozoic re-deformation of the Chinese Tien Shan Range, Central Asia. Geology, 18: 128-131.

Zeitler, P.K., 1985. Cooling history of the NW Himalaya. Tectonics, 4: 127-151.

Zuber, M.T., 1987. Compression of oceanic lithosphere: an analysis of intraplate deformation in the central Indian Basin. J. Geophys. Res.. 92: 4817-4825. 